The Changing Position of Religious Minorities in English Law:

The Legacy of Begum

\author{
Russell Sandberg* \\ Cardiff University
}

The school is often seen as a microcosm of wider society. It is therefore fitting that decisions made by schools have made a significant impact on the debate concerning the extent to which religious and racial diversity should be accommodated, a question that has dominated the public discourse in the wake of September $11^{\text {th }} 2001$. Three cases concerning schools reflect the changing extent to which and means by which English law accommodates religious and racial difference. This chapter seeks to explore the changing face of English law by reference to these three decisions: $R v$ Secretary of State for Education and Employment and others ex parte Williamson in 2005 (hereafter 'Williamson'), $R$ (on the application of Begum) $v$ Headteacher and Governors of Denbigh High School in 2006 (hereafter 'Begum') and R (on the application of Watkins-Singh) v The Governing Body of Aberdare Girls' High School in 2008 (hereafter 'Watkins-Singh'). Building upon previous work (Hill and Sandberg, 2006; 2007 and Sandberg, 2008), it contends that the reasoning of Begum has set an unfortunate and flawed precedent that has constrained religious liberty in England and Wales.

\title{
The Human Rights Act 1998
}

The face of English law had already been changed before these cases (Doe and Sandberg, 2009). The Human Rights Act 1998 had ushered in a more rights driven approach to civil liberties. The largely negative but flexible protection provided by the common law was superseded by the protection of religious liberty as a positive right. A previous legislative and judicial stance of passive accommodation had been replaced by prescriptive regulation (see King, 2007: chapter 5; Hill and Sandberg, 2006, 2007: 490). The Human Rights Act 1998 largely incorporated the European

\footnotetext{
* I am grateful to my colleagues at the Centre for Law and Religion at Cardiff University, especially Professor Norman Doe (the Centre's Director), Professor Mark Hill, Frank Cranmer, Paul Colton and Layla Wilkie-Buckley for their invaluable assistance in refining the ideas expressed here.
} 
Convention on Human Rights (ECHR) into English law. Previously, the ECHR simply had the status of a treaty obligation under international law: although individual petition to the European Court in Strasbourg had been permitted since 1966, domestic courts lacked the 'jurisdiction directly to enforce the rights and freedoms under the Convention' ( $R . v$ DDP ex $p$. Kebeline).

During this period, Articles of the Convention, including Article 9 which protects freedom of thought, conscience and religion, were simply regarded as an aid to interpretation; although English courts sought to ensure that their decisions conformed to the ECHR, they were under no obligation to follow it, and the decisions of the European Court of Human Rights, slavishly to the letter (Hill and Sandberg, 2007: 491). This is well illustrated by the case of Ahmad v Inner London Education Authority in 1978 concerning a Muslim school teacher, who was employed full time but sought to take 45 minutes off every Friday for prayer. He left his employment claiming constructive unfair dismissal. The Court of Appeal dismissed his claim, holding that the termination of employment was consistent with domestic education and employment law. Scarman LJ dissented, holding that domestic law should be construed broadly against the ECHR. He commented that:

'society has changed since 1944: so also has the legal background. Religions, such as Islam and Buddhism, have substantial followings among our people. ... This calls not for a policy of the blind eye but for one of understanding. The system must be made sufficiently flexible to accommodate their beliefs and their observances' (at 48).

His fellow judges, however, were less enthusiastic about following the ECHR, with Lord Denning, in particular, questioning whether reference to Article 9 would help the claimant and doubted more generally whether reference to the style and form of the Convention would be helpful and sufficiently flexible if followed to the letter:

'The convention is not part of our English law, but, as I have often said, we will always have regard to it. ... We will do our best to see that our decisions are in conformity with it. But it is drawn in such vague terms that it can be used for all sorts of unreasonable claims and provoke all sorts of litigation. As so often happens with high-sounding principles, they have to be brought down to earth' (at 41). 
The Human Rights Act 1998 incorporated the positive right to religious liberty provided by Article 9 into English law and required courts to take into account though not necessarily follow ( $R$ (Alconbury Developments Ltd) v Secretary of State for the Environment, Transport and the Regions) - the decisions of the European Court at Strasbourg. However, whilst at first, the impact of the Human Rights Act 1998 in matters of religious and racial difference seemed to fulfil the predictions of Scarman LJ, following the decision in Begum suggests that it was Lord Denning's comments which were prophetic.

\section{Article 9 in Strasbourg Jurisprudence}

The changing interpretation of the Human Rights Act 1998 found in Williamson, Begum and Watkins-Singh needs to be understood in the context of the Strasbourg case law on Article 9. The European Court of Human Rights at Strasbourg generally takes a formulaic approach to religious liberty cases. In line with similar international human rights instruments on religious liberty, Article 9 ECHR provides an absolute right to both the freedom of thought, conscience and religion (known as the forum internum) and a qualified right to manifest religion or belief (the forum externum). The right to manifest one's religion or belief is qualified by Article 9(1) in that the manifestation must be 'in worship, teaching, practice and observance' and by the possible limitations in Article 9(2) which permits the State to interfere with the right if the three tests in Article 9(2) are met: the interference needs to be 'prescribed by law', be 'necessary in a democratic society' and have a 'legitimate aim' as spelled out in the Article.

Most cases are concerned with the latter qualified right. In dealing with such cases, Strasbourg organs invariably begin by stressing the importance of the right, citing the leading case, Kokkinakis v Greece, which elucidated how 'Freedom of thought, conscience and religion is one of the foundations of a "democratic society" within the meaning of the Convention'. Although they then ask whether Article 9(1) has been interfered with or has been engaged, this is often a formality and the focus shifts to the Article 9(2) limitations, which are used to determine whether the limitation by the State was justified. Since the Article 9(2) limitations have an 'elastic character' 
(Sandberg, 2006: 455) this allows the court to consider the merits of the case, before reaching an appropriate conclusion.

The Strasbourg focus is upon whether the interference with the right to manifest is justified rather than whether there was an interference with the right to manifest. The threshold in relation to interference is low. The battleground is generally Article 9(2) rather than Article 9(1). This is particularly true in relation to more recent decisions of the Strasbourg court. Earlier decisions tended to rely more upon filtering devices to exclude superfluous claims. Three such devices were developed: first, the definition of belief filter, stating that Article 9 would only protect a worldview held with 'a certain level of cogency, serious reflection and importance' (Campbell and Cosans $v$ United Kingdom); second, the manifestation / motivation requirement requiring that the claimant's actions manifest their religion or belief as opposed to being merely motivated by it (Arrowsmith $v$ United Kingdom); and third, the specific situation rule, recognising that a person's Article 9 rights may be curtailed by the particular situation of the individual claiming that freedom (Ahmad v United Kingdom).

These devices are relied upon less and less by Strasbourg organs. The manifestation/motivation requirement is not always applied and when it is, the test has often been rephrased as requiring, for example, that the action is 'intimately linked' to the claimant's religion or belief (Knights, 2007: 44); a requirement which is seemingly more elastic and less strict. The specific situation rule has limited application, applying only where someone has voluntarily submitted to a voluntary system of rules, typically by voluntarily submitting to military service or a contract of employment (Hill and Sandberg, 2007: 495). Although Strasbourg institutions seemed to go further in Jewish Liturgical Association Cha'are Shalom Ve Tsedek v France by imposing an 'impossibility test' requiring that an 'alternative means of accommodating religious beliefs had ... to be "impossible" before a claim of interference under article 9 could succeed', later Strasbourg decisions have not followed this (Hill and Sandberg, 2007: 495).

Indeed, more recent cases have seen a change in approach with Strasbourg taking 'a broader view of what amounts to an interference' (Knights, 2007: 44) and giving more attention to the Article 9(2) limitations rather than the semantics of Article 9(1). 
In Thlimmenos $v$ Greece, for example, the Court simply accepted that the 'set of facts' complained of 'falls within the ambit' of Article 9 since it was 'prompted' by the claimant's religion or belief and noted that it did 'not find it necessary' to examine whether the facts 'amounted to interference with his rights under Article 9(1)'. In Sahin v Turkey, the Court proceeded on the assumption that the regulations in issue, which placed restrictions of place and manner on the right to wear the Islamic headscarf in universities, constituted an interference with the applicant's right to manifest her religion. These cases convey a preference on the part of Strasbourg institutions whereby the use of filtering devices is minimised and attention is paid instead to the question of whether the interference was justified.

\section{The Impact of Williamson}

The incorporation of Article 9 into domestic law effective from October 2000 originally led English courts to follow the trend set by Strasbourg. This was epitomised by the House of Lords decisions in Williamson. The case was brought by head teachers, teachers and parents of children at four independent schools where discipline was enforced by the use of mild corporal punishment. They contended that the ban on corporal punishment in schools (Education Act 1998, s. 548) was incompatible with their belief that physical punishment was part of the duty of education in a Christian context and so infringed, inter alia, Article 9 ECHR. While lower courts sought to exclude the claim largely by reference to the Article 9(1) right, the House of Lords focussed on the Article 9(2) limitations and specifically ruled out the use of filtering devices.

Lord Walker of Gestingthorpe, doubted whether it was right for courts, except in extreme cases, 'to impose an evaluative filter' at the stage of identifying whether there was a belief, 'especially when religious beliefs are involved' (para 57). Lord Nicholls was adamant that while Courts may be concerned with whether the claim of religious belief was made in good faith, they are not concerned whether the religious belief professed is $a$ good faith in terms of judging the validity of that faith (para 22; Sandberg, 2008). Although both Lord Nicholls and Lord Walker defended the use of the Strasbourg manifestation rule, they seemed to support the re-formulated and relaxed version of this rule focussing upon whether the act is " intimately linked" to 
the belief' and clarifying that this does not mean 'that a perceived obligation is a prerequisite to manifestation of a belief in practice' (see paras 31 and 62). Lord Nicholls also rejected the application of the 'specific situation' rule as in this case the rule did not apply on the facts since there was 'no comparable special feature affecting the position of the claimant parents' (at para 39). He also rejected as unrealistic the submission of the Secretary of State that there has been no interference: the law 'left open to the parents several adequate, alternative courses of action' (para 40-41).

After considering but rejecting all three filtering devices, the House followed a typical Strasbourg approach finding that although there had been interference with the applicants' Article 9 rights, this was justified under Article 9(2) as being prescribed by law, necessary in a democratic society for the protection of the rights and freedoms of others, and as having a legitimate aim to protect children as a vulnerable group and promote their well being. The House of Lords attracted much praise for following 'a classic human rights approach' (Langlaude, 2006: 345). Lord Walker, in particular, contended that a holistic approach to the Article should be taken since 'the issues of engagement, interference and justification are in truth closely linked together' (para 57). This approach and that of Lord Nicholls has been welcomed (Langlaude, 2006; Hill, 2007: 31). By contrast, the different approach of Lady Hale focussing upon 'children's rights' has been criticised (Langlaude, 2006: 344-345): as Hill (2006) has noted 'The purposive sociology of Baroness Hale may inspire liberal attitudes but it makes advising clients in Swindon County Court next to impossible'.

Following Williamson, the lower courts began to develop a considered jurisprudence on Article 9, following the trend set by Strasbourg. The High Court in Khan v Royal Air Force Summary Appeal Court recognised this, noting that while in 'earlier years the Commission in particular has often appeared to take a rather formal approach to Art.9(1)' and there appeared 'to have been some unwillingness to allow for the possibility of the engagement of Art.9(1) and thus to get into the question of justification under Art.9(2)', it was possible to detect a 'new preparedness to allow for possibilities that state interference under Art.9(1) may have to be justified' (para 95). This change in English jurisprudence was demonstrated by the decision of the Court of Appeal in Copsey $v$ WBB Devon Clays Ltd. Although the claimant was 
unsuccessful in his claim that his dismissal for refusing to agree to a contractual variation in his working hours to in produce a rotating shift procedure which included some Sunday working was unfair, the Court provided a refined analysis of Article 9, stressing the importance of considering Article 9(2) and singling out the Strasbourg specific situation rule for criticism. Mummery LJ, for instance, noted that the 'specific situation' rule was simply constituted of 'repeated assertions unsupported by the evidence or reasoning that would normally accompany a judicial ruling' which were 'difficult to square with the supposed fundamental character of the rights' (para 35), he declared that if there had been no such authority, he would have thought it necessary to examine the arguments under Article 9(2) (para 30).

Other cases, however, did not follow the approach in Williamson. For example, whilst some ecclesiastical court decisions on exhumation and Article 9 (such as $R e$ Durrington Cemetery) were exemplary, the judgement of Chancellor Bursell in Re Crawley Green Road Cemetery, Luton seemed to overstate the importance of Article 9 by presenting it as an absolute right which trumps domestic law (Sandberg, 2006). Nevertheless the general trend was that lower courts followed the Strasbourgcomplaint approach favoured by the House of Lords in Williamson. However, this trend was upset by another House of Lords decision, that of Begum.

\section{The Impact of Begum}

The case concerned Begum's wearing of the long jilbab coat in a state school contrary to the school's uniform policy; she contended that she had been 'excluded/suspended' from the school in breach, inter alia, of Article 9. At all three levels, the courts struggled with the interpretation of Article 9 (Hill and Sandberg, 2006). The High Court focussed on the issue of exclusion but noted that if she had been excluded, she would have been 'excluded for her refusal to abide by the school uniform policy rather than her beliefs as such' and since this would only have been 'motivated by religious beliefs', there had been no interference with her Article 9(1) right (paras 7274). This assertion that insistence on wearing religious dress does not constitute a manifestation of one's religion or belief per se seems questionable (Hill and Sandberg, 2007: 496). 
The Court of Appeal, in holding that there was a breach of Article 9, took a different approach. Its treatment of Article 9(1) was exemplary: the Court held that there was interference with Article 9 and noted that the specific situation rule had no application. Brooke LJ claimed that he was unable to derive any assistance from the cases the court was shown which related to employment disputes (para 62) while Mummery LJ concurred, noting that it was no answer that she could have attended school if only she had worn the uniform and that it was irrelevant that she could have changed schools to accommodate her religious beliefs since she was not in the same position as an employee; rather there was a statutory duty to provide education and the school did not follow the proper statutory procedure for excluding her (para 84).

However, the Court of Appeal erred in relation to the application of Article 9(2). Rather than deciding whether the restriction on the right to manifest prescribed by school uniform could be justified as being necessary in a democratic society, Brooke LJ outlined the decision-making structure which the school should have used since, on his findings, the onus lay on the school to justify its interference with the Convention right (para 75-76). This rests on a basic mistake: whilst courts apply such a proportionality test when reviewing decisions of public authorities after they have been made, there is nothing in the Human Rights Act 1998, the ECHR or Convention jurisprudence that requires public authorities themselves to adopt a proportionality approach to the structuring of their own decision-making (Poole, 2005). The Court of Appeal hid 'under the blanket of procedure' producing a regrettable and erroneous approach imposing 'a stifling culture of formalism on public administrators that is quite at odds with the substantive objectives' of the Human Rights Act 1998 (Poole, 2005: 694).

The House of Lords decision corrected the Court of Appeal's overly formulaic interpretation of Article 9(2). However, rather than following the Court of Appeal's exemplary treatment of Article 9 (1) the majority of the House of repeated and compounded the error originally made by the High Court (Hill and Sandberg, 2007: 497). Lords Bingham, Hoffmann and Scott held that there had been no interference with the applicant's rights under Article 9(1). Lord Bingham held that although Article 9(1) of the ECHR was 'engaged or applicable' because Begum sincerely held the religious belief which she professed to hold (para 21), Article 9 does not protect 
all acts motivated or inspired by belief (para 22). He summed up the 'specific situation' rule developed by Strasbourg thus:

'The Strasbourg institutions have not been at all ready to find an interference with the right to manifest religious belief in practice or observance where a person has voluntarily accepted an employment or role which does not accommodate that practice or observance and there are other means open to the person to practise or observe his or her religion without undue hardship or inconvenience' (para 23).

This ignores the move against such filtering devices in Strasbourg jurisprudence and suggests that the interference requirement is rarely met. No reason was given for the application of the specific situation rule to the school environment where there is no contractual relationship between the pupil and the school (Hill and Sandberg, 2006). Moreover, although Lord Bingham's elucidation of the specific situation rule required both voluntary acceptance of a rule and an alternative means to manifest religion or belief, Lord Bingham seemed to place great emphasis upon this second limb: he held that there was no interference with Begum's right to manifest her belief in practice or observance since Begum's family chose the school from outside their own catchment area and that there was 'no evidence to show that there was any real difficulty in her attending' another school (para 25). This conclusion, supported by Lords Hoffmann and Scott, suggests that provided there is a choice then an applicant's Article 9 right to manifest is not even engaged. This point brings domestic law in line with the muchcriticised Strasbourg case of Jewish Liturgical Association Cha'are Shalom Ve Tsedek $v$ France. This is particularly disturbing since both Lord Hoffmann and Lord Bingham followed Williamson in questioning the correctness of this case.

Lord Bingham's further elucidation of the rule proved even more suspect: quoting selectively from numerous Strasbourg and domestic cases on the 'specific situation' rule, Lord Bingham omitted to mention references to the caveats to the rule, and applied the rule to the facts of the case without explanation (Hill and Sandberg, 2007: 497). Although he recognised the view of the Court of Appeal in Copsey $v$ WBB Devon Clays Ltd, he effectively gave the specific situation rule general application by concluding that:

'Even if it be accepted that the Strasbourg institutions have erred on the side of strictness in rejecting complaints of interference, there remains a coherent and 
remarkably consistent body of authority which our domestic courts must take into account and which shows that interference is not easily established' (para 24).

This very broad proposition that 'interference is not easily established' seems to overstate the law. The Court of Appeal judgement in Copsey v WBB Devon Clays Ltd and more recent Strasbourg decisions question whether the body of authority should be followed as being coherent and consistent. Reliance on the specific situation rule was also unnecessary since if it was simply accepted that Article 9 was engaged, the claim could nevertheless be defeated by the use of one or more of the Article 9(2) limitations (Sandberg and Hill, 2006; 2007).

The preferable reasoning is that of the minority, who concurred with the majority in the ultimate disposal of the appeal (Hill and Sandberg, 2007: 498; Knights, 2007: 48). Lord Nicholls and Lady Hale recognised that Article 9 had been engaged but that the interference was justified under Article 9(2). However, it is unfortunate that their speeches did not explain why their approach was the consistent interpretation of the Strasbourg jurisprudence. Although the House of Lords judgement in Begum includes helpful obiter dicta, such as passages correcting the Court of Appeal's procedural approach and hinting at a domestic 'margin of appreciation' (see paras 34,63-64) it is a matter of regret that the ratio of the case is flawed. Giving universal effect to the specific situation rule and then rigidly applying it as a filtering device was likely to be problematic in terms of precedent. Although the speeches of the majority considered Article 9(2) in obiter and thus gave consideration to the merits of the case, a future court would not be obliged to do so. The majority's unnecessary and erroneous treatment of Article 9(1) had the clear potential of undoing the legacy of Williamson.

The case law following Begum suggested that the reasoning of the majority had undone the legacy of Williamson, with the overly narrow approach of the majority being adopted uncritically by lower courts and tribunals (Hill and Sandberg, 2007: 498; Hill, 2007: 31; Sandberg, 2008). In $R$ (on the application of X) v Y School the High Court regarded the Begum decision as an 'an insuperable barrier' (para 100) to a claim for judicial review by a twelve year old school girl who wished to wear a niqab veil while she was at school and being taught by male teachers or when she was likely to be seen by men (Hill and Sandberg, 2007: 498-499). Drawing on Lord Bingham's 
elucidation of the 'specific situation' rule in Begum, Silber J interpreted this as meaning that there would be no interference either where a person has voluntarily accepted an employment or role that does not accommodate that practice or observance $o r$ where there are other means open to practise or observe that religion without undue hardship or inconvenience (para 26). Although this goes further than Lord Bingham who said that both requirements were needed, this is not unsurprising since it takes the majority's reasoning in Begum to its natural conclusion by giving general effect to the specific situation rule, bringing English law in line with the discredited 'impossibility' test provided in Jewish Liturgical Association Cha'are Shalom Ve Tsedek v France (Hill and Sandberg, 2007: 448).

Although more recent civil cases have not gone quite as far as $R$ (on the application of $X)$ v Y School, they have shown a stricter approach to Article 9(1) than was the case prior to Begum (Sandberg, 2008). In $R$ (on the Application of Playfoot (A Child) $v$ Millais School Governing Body the High Court rejected an application for judicial review on behalf of a school girl who had wanted to wear a 'purity' ring at school as a symbol of her religiously-motivated commitment to celibacy before marriage.

Michael Supperstone QC, sitting as a Deputy High Court Judge, held that Article 9 was not engaged since the wearing of the ring was not a manifestation of her religious belief: it was not 'intimately linked' to the belief in chastity before marriage because the claimant was under no obligation, by reason of her faith, to wear the ring. This seems at odds not only with the more liberal application of the motivation / manifestation distinction found in the speech of Lord Nicholls in Williamson and recent Strasbourg jurisprudence but also runs the risk of infringing the wellestablished principle emphasized by Lord Nicholls in Williamson that courts should not be concerned whether the religious belief professed is a good faith in terms of judging the validity of that faith (Sandberg, 2008). Determining whether an action is a manifestation of a person's religion or belief by determining whether that action was mandated by that person's religion as interpreted by a Deputy High Court Judge seems inappropriate.

Moreover, the High Court in Playfoot also invoked the post-Begum version of the specific situation rule. The judge held that there was no interference with Article 9 since the claimant had voluntarily accepted the school's uniform policy and there 
were other means open to her to practise her belief without undue hardship or inconvenience (para 32). This conclusion not only follows Begum in accepting that the rule applies to schoolchildren but also follows Begum in casting the rule as one of general application. The judge placed emphasis upon this argument, noting that the claimant could have expressed her belief in another way, for example by attaching the ring, a key ring or other visible signs to her school bag or by transferring to another school which would allow the wearing of the ring. These comments suggest that the 'specific situation' aspect of the 'specific situation' rule is increasingly broader in domestic case law than in the Strasbourg jurisprudence. The rule has moved beyond its original contractual setting and the scope of the rule is now unknown (Sandberg, 2008). The reasoning of the High Court is a matter of regret, given that the same decision could be made in a more Strasbourg-complaint manner by simply holding that there had been interference with Article 9 and that interference would have been justified under Article 9(2). Although the High Court to date has followed the House of Lords in Begum in undertaking some analysis of Article 9(2), this analysis has been purely obiter, allowing courts in the future to base their decisions solely on the lessconvincing dicta concerning whether or not Article 9 was engaged.

It is also of concern that commendable elements of the House of Lords judgement in Begum have been forgotten. This is clear from High Court and Court of Appeal decisions in $R$ (on the Application of Swami Suryananda) $v$ Welsh Ministers concerning whether the slaughter of Shambo, a bullock at the claimant's Hindu temple, which had tested positive for the bacterium that causes bovine tuberculosis (TB), breached the claimant's human rights (Sandberg, 2008). In the High Court, whilst the applicability of Article 9(1) was quickly accepted, confusion arose in relation to the application of Article 9(2) in that the judge quashed the decision by the Welsh Ministers (to order the slaughter) on the basis that they had failed to approach the balancing exercise required under Article 9(2) since they had not identified a public interest to balance against the individual rights of the Community; rather, they had defined their legitimate object too narrowly to be a proper public interest objective for the purposes of Article 9(2). The Court of Appeal unanimously allowed the appeal, criticising the High Court for erroneously focussing upon the 'whether the decision maker proceeded in the right way', when the focus should have simply been on 'whether the decision taken does or does not infringe the relevant rights' (para 
103). The High Court had made the same mistake as the Court of Appeal in Begum.

The Court of Appeal, however, followed a classic human rights and Strasbourgcompliant approach by using the Article 9(2) limits to hold that the interference was justified, thereby setting aside the order quashing the slaughter notice (Sandberg, 2008). However, despite the decision of the Court of Appeal in Swami Suryananda $v$ Welsh Ministers, the decision in Watkins-Singh was to demonstrate that the effect of Begum was to leave Article 9 moribund.

\section{The Impact of Watkins-Singh}

The case concerned Sarika Angel Watkins-Singh, a fourteen year old girl of PunjabiWelsh heritage, who attended Aberdare Girls’ High School. After being asked to her to remove her kara, defined judicially as 'a plain steel bangle which has a width of about 50 millimetres' (para 1), since it contravened the school's uniform policy, she unsuccessfully sought an exemption from the policy on the basis that her kara was a matter central to her ethnic identity and religious observance which meant that she was taught in isolation and then educated at Mountain Ash School, which permitted the wearing of a kara. The Governing Body of the School had refused the request for an exemption on Article 9 grounds. Invoking the language of the post-Begum domestic specific situation rule, the Governors originally refused on the basis that it has 'not been convinced that, as part of her religion, it was a requirement that the kara be worn on the wrist, that if it were allowed this may result in bullying from other pupils and the wearing would give rise to health and safety issues' (para 16). The Appeal Committee of the Governing Body was even more specific, refusing a subsequent appeal on the basis that 'article 9 of the ECHR does not require that one should be allowed to manifest one's religion at any time and place of one's choosing' (para 17). Watkins-Singh challenged the decisions of the Governing Body of the school contending that they were based on errors of law.

Crucially, whilst the school saw the case as concerning Article 9 and therefore likely to be unsuccessful due to Begum, Watkins-Singh's legal team did not argue the case on Article 9 grounds. Rather, it was argued that the refusal to allow Watkins-Singh to wear the Kara at school was unlawful as indirect unjustified race and religious discrimination contrary to the Race Relations Act 1976 and the Equality Act 2006. A 
number of other claims were also made, most notably that the defendant had not complied with the general statutory duty under section 71 of Race Relations Act 1976, but the only human rights based claim was a contention that the segregation of Watkins-Singh contravened her rights under Articles 8 and 14 of the ECHR. The difference between Watkins-Singh and the previous religious dress cases was elucidated by Silber $\mathbf{J}$ at the start of his judgment: he noted that unlike the previous cases of Begum, $X \vee Y$, and Playfoot which were 'founded largely, if not solely on the provisions of the Human Rights Act 1998', the claim in the present case was 'based mainly on the totally different provisions' of the Race Relations Act 1976 and the Equality Act 2006, 'provisions on which the claimants in the previous case were unable to rely on' (para 3). The previous claimants had been unable to rely on race discrimination laws since adherents of Islam and Christianity are not seen as races whilst Sikhs and Jews are (Mandla v Dowell Lee; Seide v Gillette Industries Limited cf. J H Walker Limited v Hussain and Others). Part 2 of the Equality Act 2006 which extended religious discrimination to cover goods and services and the exercise of public functions was not in force at the time of the earlier cases.

The claim for indirect discrimination on grounds of religion and race was upheld. In so holding Silber J employed a much more generous approach to religious symbols which are not mandated by the religion in the discrimination law context, than the High Court did in Playfoot in the human rights context. In Watkins-Singh, the question of whether the wearing of the kara was obligatory to the claimant was sidestepped. Although the expert evidence suggested that it was the initiated Sikhs who observed all five Ks, of which the kara was one, and Watkins-Singh was an observant non-initiated Sikh, the expert also suggested that of the five Ks, the kara was the symbol most commonly worn. Silber J held that in relation to claims of indirect discrimination, he was unable to accept the defendant's contention that there would be a disadvantage only where a member of the group is prevented from wearing something that they are required to wear (para 51). This threshold was too high: the language of the provisions do not suggest such a threshold, such an interpretation would require rewriting the legislative provision, would be inconsistent with the approach in recent Strasbourg jurisprudence, has no authority and has no valid reason of principle. Silber J commented that: 
'the court should not impose too high a threshold in seeking to establish prima facie discrimination as to do so would undermine the intension of the legislation' (para 67).

He therefore concluded that disadvantage would occur - but would not only occur where a pupil is forbidden from wearing an item where 'that person genuinely believed for reasonable grounds that wearing this item was a matter of exceptional importance to this or her racial identity or his or her religious belief' and where 'the wearing of the item can be shown objectively to be of exceptional importance to his or her religion or race, even if the wearing of the article is not an actual requirement of that person's religion or race' (para 56B). Both the subjective and objective elements are satisfied on the facts: nothing had been suggested to undermine the truthfulness of Watkins-Singh's comments and the wearing of the item can be shown to be of exceptional importance to her religion and race as a Sikh even if not a requirement of that religion or a race. The reasons given by Silber $\mathbf{J}$ are strong and raise the question why the same conclusion ought not to be applied in the human rights context. By relying on Strasbourg cases for the 'exceptional importance' test Silber J's judgment questions the sharp distinction drawn in Playfoot.

Moreover, ironically in this case agued on discrimination grounds, the High Court cited and followed the dicta in Williamson concerning how a court should decide whether a claimant is genuinely manifesting a religious belief: Silber J noted that whilst the court may inquire into the genuineness of a claimant's belief as an issue of fact, it is not for the court to inquire into its validity. This again questions the decision in Playfoot. Furthermore, unlike the cases argued on Article 9 grounds, questions of justification were not mere obiter statements in Watkins-Singh. Interestingly Silber J again sought to distinguish the instant case from the Article 9 case law: 'decisions on justification which were successfully used by schools in the Begum, Xv Y School and Playfoot cases' did not apply since 'many of the aspects of justification relied on in those cases are related to the extremely clearly visible and very ostentatious nature of the religious dress ought to be worn' (para 78). However, this distinction is suspect. Silber $\mathbf{J}$ contended that it could not be said that allowing pupils to wear a kara causes substantial difficulties because they may stand out and that it undermined the uniform policy's aim of fostering a community spirit because the kara is small and is usually hidden by a long-sleeved sweater. This may be true in 
relation to the cases on Muslim dress but this was hardly true of the ring in Playfoot. The argument that the kara, unlike a ring, could be covered up is erroneous on two grounds: first, the kara was seen by the teacher on the day in which Watkins-Singh was asked to remove it; second, as Silber J's language conceded it was simply the case that it was 'usually' covered by a long sleeve as opposed to always covered. Surely, obtrusiveness was ultimately irrelevant to the issue. Silber J sought to distinguish the justifications put forward in Playfoot on the grounds that in the instant case it could not be said that the ban was justified in that it minimised pressures resulting from wealth and style. However, this sees the purity ring in Playfoot as simply a fashion accessory: a conclusion undermined by the fact that the lifestyle it symbolises is, if anything, out of fashion. A watertight distinction between the justifications accepted in the previous cases and the justifications rejected in the instant case is unsustainable.

Silber J also rejected the 'floodgates' argument on the basis that it was far from obvious that other pupils would be able to invoke this exception which is dependent on two factors: the first is that both the subjective and objective tests would have to be met: 'the belief of the pupil justified by objective evidence that the wearing of the article is a matter of exceptional importance as an expression of race and culture'; the second is the 'unobtrusive nature of the kara' (para 92). However, this need for 'objective evidence' also raises the risk of courts engaging in issues upon which Williamson establishes that they should not tread since determining that 'evidence' invariably stretches if not defies the Williamson principles concerning the role of the court. Watkins-Singh is preferable to the Article 9 case law in that it does not fail at the interference stage. However, although Watkins-Singh is welcome in that it does not say that a religious manifestation has to be mandatory to be protected, WatkinsSingh disappoints in setting a high threshold for protection in the case of a religious manifestation which is not mandatory which suggests that both an objective and subjective test is required. It would be far preferable for the question of justification to be decisive.

It is of interest that all the other various claims made in Watkins-Singh succeeded apart from the human rights based one. The segregation of Watkins-Singh did not contravene her rights under Articles 8 and 14 of the ECHR; it was necessary to 
proceed on the basis that she was content at school, Article 8 was not infringed. This claim did not add anything to the claim of indirect discrimination (para 137). This was telling of the approach generally taken: Watkins-Singh was not argued on Article 9 grounds because it is likely that on Article 9 grounds it would have failed, as the school governors readily understood. The case was successful because it seemed that the school, its teachers or its governors had not been informed, let alone instructed, on the significance of discrimination law generally and particularly to the dispute. Although the new law on religious discrimination offers a means of protecting religious freedom in lieu of Article 9, the restriction of Article 9 post-Begum remains lamentable. Silber J's comments concerning whether a religious undertaking needs to be mandatory and the proper role of the court in Watkins-Singh are to be welcomed. However, the threshold imposed in relation to interference still seems too high. Many cases - even those argued on discrimination rather than Article 9 grounds - will continue to fall at the first hurdle. Surely the preferable approach would be to focus on the question of justification rather than saying that a religious practice must be mandatory or virtually mandatory (which is what Silber J's 'exceptional importance' test amounts to) before their religious freedom is infringed. Focusing on the question of justification would mean that if Watkins-Singh was successfully decided, then the decision in Playfoot is suspect. The mere fact that Article 9 was not argued in Watkins-Singh is important. It seems to suggest that Begum has restricted the application of Article 9 to such an extent that it has become moribund, at least in relation to claims concerning religious dress.

\section{Conclusions: The Legacy of Begum}

The actions of the assistant head teacher of Denbigh High School on the first day of the school term in September 2002, in telling Shabina Begum to go home, change and return wearing school uniform must have seemed at the time to be rather mundane and ordinary. Yet, the judicial deliberations that followed provided 'a confusing and unhelpful precedent' that constrained religious liberty in England and Wales (Hill and Sandberg, 2007: 498), being regarded as an insuperable barrier by the judiciary ( $X v$ $Y$ School, para 100) and being disregarded by litigants (such as the claimant in Watkins-Singh) who now, it appears, seek to rely on anything but Article 9. 
Given the traditional judicial reluctance to intervene in matters of religion (Hill, 2001), it is not surprising that the judiciary have struggled with the effects of the Human Rights Act 1998. The significance of the change is underscored by comparative reference with the even later incorporation of the ECHR in Ireland (European Convention on Human Rights Act 2003) which has had less effect and has led to little case law because of the pre-existing constitutional protection of religion. Even after the incorporation of the ECHR into Irish law, 'the principal (if not all) cases involving questions of religious freedom or religious issues per se have been determined in Ireland with reference to the provisions of Bunreacht na hÉireann rather than to the ECHR' (Colton, 2007). The UK's Human Rights Act 1998, by contrast, provided a constitutional and cultural shift. It was thus unsurprising that the judiciary in this new task became entangled quite unnecessarily in the semantics of the right rather than the merits of the case. The focus on questions of interference rather than justification led judges to rely unduly upon filtering devices, most notably the general application of the specific situation rule in Begum.

Whilst prior to Begum, lower courts and tribunals generally followed the 'classic human rights approach' taken by the House of Lords in Williamson (Langlaude, 2006: 345), after Begum, lower courts and tribunals generally adopted an overly restrictive interpretation of the Article 9(1) right, with domestic courts falling into problems which have largely been avoided by Strasbourg institutions (Sandberg, 2008). The arguments deployed in Watkins-Singh, their success and Silber J's reasoning are all part of the legacy of Begum, a case important not so much for its actual decision but for the reasoning of the majority. It remains to be seen how the legacy of Begum will affect subsequent higher court decisions on religious freedom.

Reference to the changing face of English law, as demonstrated in the cases of Williamson, Begum and Watkin-Singh, provides a deeper understanding of issues of cultural difference which are reduced to 'moral panics' (Cohen, 1972) by the media. Such legal analysis is of particular importance at a time in which the legal framework appears to have changed (Doe and Sandberg, 2009) and further change to the constitution is mooted (see Cranmer, 2009). Reference to changing legal interpretations provide a valuable insight into the complex relationship between religion, law and society, or to be more precise, religions, laws and societies 
(Bradney, 2001: 81). However, a legal approach in isolation may not be sufficient (Sandberg, 2009). For instance, in Begum wider political and social trends - such as the fact that it was clear that the girl in question had come through her brothers under the influence of Hizb u Tahrir, an extremist religious organisation, in particular, and the backdrop of September $11^{\text {th }}$ and July $7^{\text {th }}$, in general, - shaped the bringing of the claim, the way in which it was argued and the response of the judiciary. Analysis of the reasoning provided in law reports in isolation cannot provide a complete picture of changing social norms, yet it does provide a valuable and often neglected contribution to wider debates (Twinning, 1994). In the on-going debate concerning the extent to which religious and racial diversity should be accommodated in England and Wales, these three cases concerning schools are of considerable importance.

\section{Table of Cases}

Ahmad v Inner London Education Authority [1978] QB 36

Ahmad v United Kingdom (1981) 4 EHRR 126

Arrowsmith v United Kingdom (1981) 3 EHRR 218

Campbell and Cosans v United Kingdom (1982) 4 EHRR 293

Copsey v WBB Devon Clays Ltd [2005] EWCA Civ 932

Jewish Liturgical Association Cha'are Shalom Ve Tsedek v France (2000) 9 BHRC 27

J H Walker Limited v Hussain and Others [1996] ICR 291

Khan v Royal Air Force Summary Appeal Court [2004] EWHC 2230

Kokkinakis v Greece (1994) 17 EHRR 397

Mandla v Dowell Lee [1983] 2 AC 548

Re Crawley Green Road Cemetery, Luton [2001] Fam 308

Re Durrington Cemetery [2001] Fam 33

$R$ (Alconbury Developments Ltd) v Secretary of State for the Environment, Transport and the Regions [2001] UKHL 23 
$R$ (Amicus MSF Section) v Secretary of State for Trade and Industry [2004] EWHC 860, [2004] IRLR 430

$R$ (on the application of Begum) $v$ Headteacher and Governors of Denbigh High School [2004] EWHC 1389; [2004] EWHC 1389; [2006] UKHL 15

$R$ (on the Application of Playfoot (A Child) v Millais School Governing Body [2007] EWHC Admin 1698

$R$ (on the Application of Swami Suryananda) v Welsh Ministers [2007] EWHC (Admin) 1736; [2007] EWCA Civ 893

$R$ (on the application of X) v Y School [2006] EWHC (Admin) 298

$R v$ Secretary of State for Education and Employment and others ex parte Williamson [2005] UKHL 15

$R v$ DDP ex parte Kebeline [2000] 2 AC 326

Sahin v Turkey (2005) 41 EHRR 8

Seide v Gillette Industries Limited [1980] IRLR 427

Thlimmenos v Greece (2001) 31 EHRR 15

\section{Bibliography}

A Bradney, (2001) 'Politics and Sociology: New Research Agenda for the Study of Law and Religion' in R O'Dair and A Lewis, Law and Religion, (Oxford University Press, Oxford)

S Cohen, (1972) Folk Devils and Moral Panics (St Martins Press)

P Colton, (2007) 'Ireland, the European Convention on Human Rights and Freedom of Religion' (paper submitted to the European Consortium for Church and State Research, November 2007 Consortium).

F Cranmer, (2009) 'Human Rights and the Christian Tradition: A Quaker Perspective' in N Doe and R Sandberg, (ed), Law and Religion: New Horizons (Peeters, Leuven)

N Doe and R Sandberg, (2009) 'Conclusion: New Horizons' in N Doe and R Sandberg, (ed), Law and Religion: New Horizons (Peeters, Leuven)

M Hill, (2001) 'Judicial Approaches to Religious Disputes' in R O'Dair and A Lewis (eds), Law and Religion (Oxford University Press, Oxford)

M Hill, (2002) 'A New Dawn for Freedom of Religion' in M Hill (ed), Religious Liberty and Human Rights (University of Wales Press, Cardiff) 
M Hill, (2006) 'Freedom of Religion in Contemporary English Jurisprudence' (unpublished lecture to the Oxford Society for Law and Religion, delivered at Balliol College, University of Oxford on Thursday 16 March 2006)

M Hill, (2007) Ecclesiastical Law (3 ${ }^{\text {rd }}$ edn Oxford University Press, Oxford)

M Hill and R Sandberg, (2006) 'Muslim Dress in English Law: Lifting the Veil on Human Rights' 1 Religión y Derecho (Law and Religion) 302

M Hill and R Sandberg, (2007) 'Is Nothing Sacred? Clashing Symbols in a Secular World' [2007] Public Law 488

A King, (2007) The British Constitution (Oxford University Press, Oxford)

S Knights, (2007) Freedom of Religion, Minorities and the Law (Oxford University Press, Oxford)

S Langlaude, (2006) 'Flogging Children with Religion: A Comment on the House of Lords' Decision in Williamson' 8 Ecclesiastical Law Journal 335

T Poole, (2005) 'Of Headscarves and Heresies: The Denbigh High School Case and Public Authority Decision Making Under the Human Rights Act' [2005] Public Law 685

R Sandberg, (2006) 'Human Rights and Human Remains: The Impact of Dödsbo v Sweden' 8 Ecclesiastical Law Journal 453

R Sandberg, (2007) 'Flags, Beards and Pilgrimages: A Review of the Early Case Law on Religious Discrimination' 9 Ecclesiastical Law Journal 87

R Sandberg, (2008) 'Controversial Recent Claims to Religious Liberty' 124 Law Quarterly Review 213

R Sandberg, (2009) 'Religion, Society and Law: An Analysis of the Interface between the Law on Religion and the Sociology of Religion' (Cardiff University, doctoral thesis)

W Twining, (1994) Blackstone's Tower: The English Law School (Sweet \& Maxwell, London) 